\title{
Description of the larva and pupal case of Ommatius orenoquensis Bigot (Diptera, Asilidae, Ommatiinae)
}

\author{
Lucas de Araujo Cezar ${ }^{1,2} \&$ Carlos José Einicker Lamas ${ }^{1,3}$
}

\begin{abstract}
${ }^{1}$ Museu de Zoologia da Universidade de São Paulo, Avenida Nazaré, 481, Ipiranga 04263-000, São Paulo-SP, Brazil. cezar_la@hotmail.com
${ }^{2}$ Programa de Pós-Graduação em Entomologia da Faculdade de Filosofia Ciências e Letras de Ribeirão Preto, Universidade de São Paulo. Ribeirão Preto-SP, Brazil.

${ }^{3}$ Conselho Nacional de Desenvolvimento Científico e Tecnológico (CNPq), fellow.
\end{abstract}

\begin{abstract}
Description of the larva and pupal case of Ommatius orenoquensis Bigot (Diptera, Asilidae, Ommatiinae). The last instar larva and the pupal case of Ommatius orenoquensis Bigot, 1896 from a Cerrado (Brazilian Savanna) area in São Paulo, southeastern Brazil, are for the first time described and illustrated.
\end{abstract}

KEYWORDS. Immature stages; morphology; Neotropical; robber flies.

RESUMO. Descrição da larva e pupa de Ommatius orenoquensis Bigot (Diptera, Asilidae, Ommatiinae). Larva de último instar e pupário de Ommatius orenoquensis Bigot, 1896 de uma área de Cerrado no estado de São Paulo são, pela primeira vez, descritas e ilustradas.

PALAVRAS-CHAVE. Estágios imaturos; morfologia; Neotropical, asilídeos.

Asilidae is a diverse family of uniquely predacious flies. Insects of several orders (and also spiders) may be taken as prey by adults of this family, which are commonly found in open and sunny habitats. The asilid larvae are also predators of other insect larvae, especially beetles. Immature stages of robber flies are usually found in soil or decaying wood (Hull 1962; Wood 1981; Musso 1981, 1983).

Ommatius Wiedemann, 1821 comprises over 300 described species and includes representatives in all biogeographic regions. One third of these species occur in the Neotropical region. Adults from this genus are recognized by a long plumose antennal stylus, closed cell $\mathrm{m}_{1}$ and sclerotized postmetacoxal bridge (Scarbrough 1993; Geller-Grimm 2008). Scarbrough (1993) placed O. orenoquensis Bigot, 1876 into the costatus species group, which includes 14 species that share: spear-shaped flagellum, long ventral setae on fore femora and posteroventral setae on mid femora, a long and thin preapical dorsoposterior seta on the mid femora of males and also other characters. Ommatius orenoquensis is widespread in the Neotropical region, ranging from Costa Rica to Argentina.

Despite the large number of asilid species described, little is known about their immature stages. Dennis et al. (2008) estimated that for only two percent of the species diversity the immature stages are actually known. They have also made a major contribution to this knowledge describing the pupal cases of 24 Nearctic Asilidae species, including two Ommatius species. Thus, we present here the first description of an Ommatius species third instar larva along with its pupal case, for this poorly known species, Ommatius orenoquensis.

\section{MATERIAL AND METHODS}

The terminology used here is the one synthesized by Dennis et al. (2008) for pupal cases and Peterson (1960) for larvae. The material was collected as third instar larvae, from soil, close to termite nests, along with elaterid and scarabaeid beetle larvae (most probably the prey for these asilid larvae), in a Cerrado (Brazilian Savanna) area at Luiz Antonio Municipality, São Paulo, by S. P. Rosa and M. Ladenthin, on $\mathrm{V} / 22 / 2008$. All larvae collected were kept alive ex-situ, in Petri dishes with soil only, apart from the termites and beetles and unfed. Only one of the larvae developed into pupa and an imago emerged. The pupal case description refers thus to the latter. All studied material is deposited in the Museu de Zoologia da Universidade de São Paulo (MZUSP), São Paulo, Brazil.

\section{RESULTS AND DISCUSSION}

\section{Ommatius orenoquensis Bigot, 1876}

(Figs. 1 A-E, 2 A-E)

Third instar larva:

Greatest length, 16.4-25.7 mm; greatest width, 1.6-2.2 $\mathrm{mm}$; length of head, 0.6-1.4 mm; width of head (apical circular callosity), $0.4-0.9 \mathrm{~mm}$; greatest length of abdominal segment $8,0.9-1.2 \mathrm{~mm}$; greatest width of abdominal segment $8,1.5-2.0 \mathrm{~mm}$.

Body white, elongate and subcylindrical. Cephalic capsule sclerotized, much narrower than prothorax, curved 


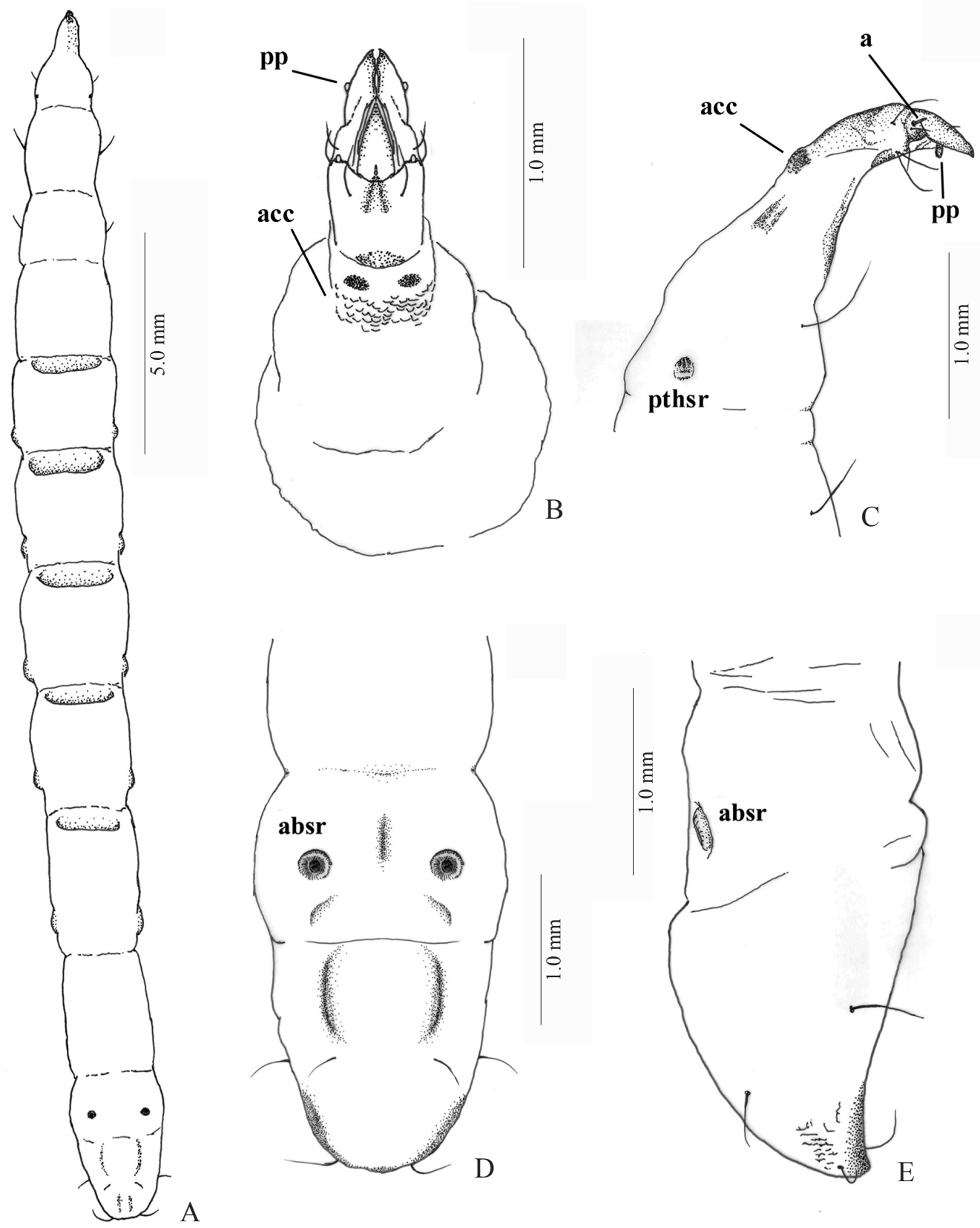

Fig. 1. Larva of O. orenoquensis: (A) Habitus (dorsal view); (B) Head (dorsal view); (C) Head (lateral view); (D) Terminal segments (dorsal view); (E) Terminal segments (lateral view). a: antenna, absr: abdominal spiracle, acc: apical circular callosity, pp: palpus, pthsr: prothoracic spiracle.

ventrally (Fig. 1A); three pairs of fine bristles dorsolaterally, three ventral pairs; palpi small, oval, inserted ventrally to the mandibles (Fig. 1B,-C); antennae reduced lighter than cephalic sclerite, inserted anterolaterally to it. One pair of fine bristles per thoracic segment; prothorax with rugose apical circular callosity; prothoracic spiracle well-developed. Abdominal segments 2-6 with conspicuous dorsal, ventral and lateral callosities (Fig. 1A); abdominal spiracles on the $8^{\text {th }}$ abdominal segment well developed (Fig. 1D,-E); inconspicuous on other abdominal segments; four pairs of fine setae on terminal segment; apical ridge flattened dorsoventrally and convex dorsally (Fig. 1E).
Pupal case:

Greatest length, including anterior antennal processes, 8.6 $\mathrm{mm}$; greatest width of head, $1.9 \mathrm{~mm}$; greatest width of thorax, $2.3 \mathrm{~mm}$; greatest width of abdomen, $1.95 \mathrm{~mm}$; tapering to $0.95 \mathrm{~mm}$ at greatest width of abdomen segment 8. Golden integument; spines and other processes reddish brown, darker apically.

Head with a pair of long, dorsoventrally flattened, medially fused anterior antennal processes (Fig. 2A) and two groups of three basally fused posterior antennal processes located ventrolaterally (Fig. 2B). Middle and third posterior processes fused for a greater distance. Posterior antennal 

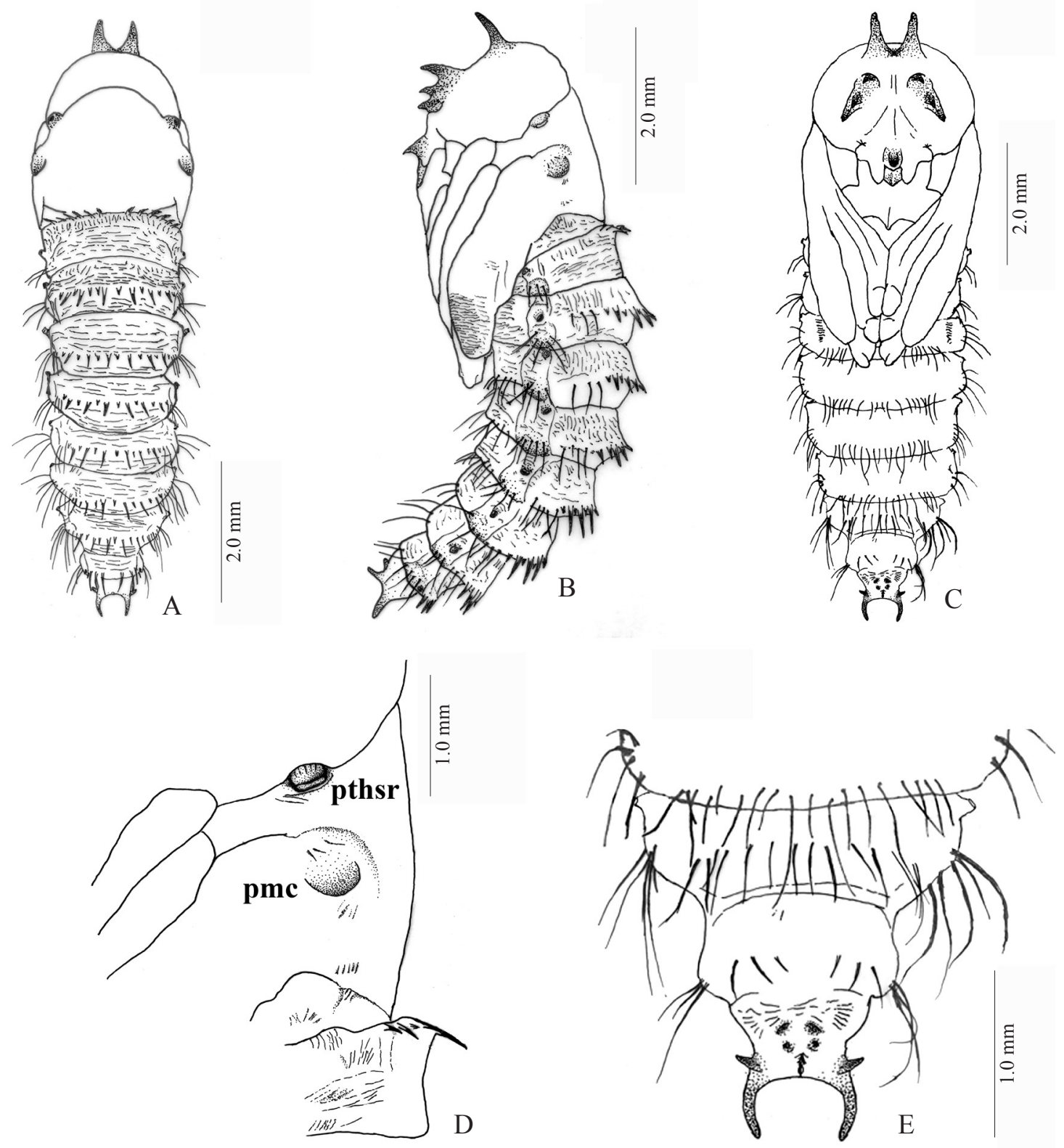

Fig. 2. Pupal case of O. orenoquensis: (A) Habitus (dorsal view); (B) Habitus (lateral view); (C) Habitus (ventral view); (D) Thorax (lateral view). pmc: posterior mesothoracic callosity, pthsr: prothoracic spiracle; (E) Terminal segment (ventral view).

processes acute apically and the hind pair with a flattened area posteriorly, as a ridge. Labral sheath bulbous composed of a large, apically rounded and darker, dorsoventrally flattened, rugose process. Proboscial sheath slightly rugose and barely concave near the middle. Maxillary sheath smooth with small median tubercule (Fig. 2C).

Anterior coxal sheath smooth, except in the middle area, with anterior median and longitudinal split. Prothoracic spiracle elongate-oval, directed posteriorly, on small, brownish, rugose callosity, situated midlaterally at anterior margin of thorax (Fig. 2D). Anterior mesothoracic spines absent. Posterior mesothoracic callosity large, mostly smooth, with sclerotized ridges, especially posteriorly. Rugose area posterior to posterior mesothoracic callosity. Wing sheath rugose on posterior third. Thoracic area above wing sheath smooth, except for small area behind posterior mesothoracic callosity. Apex of hind leg sheath reaching near the margin of abdominal segment 3 (Fig. 2B).

Abdominal spiracles upraised and stalk-like, brown, more round than prothoracic spiracle, along midline laterally. Abdominal segment 1 with dorsal transverse row of 12 mostly long, apically recurved spurs on anterior margin of segment; lacking dorsolateral bristle-like spines, but presenting 3 laterally behind each spiracle; venter obscured by wing and leg sheaths. Segments $2-7$ with dorsal transverse row of 6 long spurs alternating with 7 short spines (segment 2 presents two spines between the second and third spurs from the left); 3-5 dorsolateral bristle-like spines of unequal size 
on each side, plus 3-5 lateral bristle-like spines of unequal size behind each spiracle. Segment 2 with 6 ventral bristlelike spines on each side of the leg sheaths. Segments 3-7 with complete transverse row of 16-22 bristle-like spines of unequal size; median 2-3 bristle-like spines usually shorter than spines on each side. Segment 8 with dorsal row of 3 spurs and 1 spine at each side of the midline, small spiracle along midline laterally, 4 bristle-like spines below spiracle, and 6 ventral bristle-like spines of unequal length. Segment 9 with pair of long, dorsally curved, dorsal posterolateral processes; pair of shorter, dorsally flattened, ventrally curved, ventral posterolateral processes; pair of ventral posteromedian acuminate process; and pair of midventral, posteriorly diverging, elongate swellings (Fig. 2E).

Remarks: This pupal case differs from those of Ommatius gemma and $O$. tibialis on the length of the leg and wing sheaths and the number of bristles, spines and spurs on the abdominal segments, especially on the segment 8 . The absence of a dorsomedian bristle-like spine above the wing sheath resembles the condition noted for $O$. tibialis. The posterior antennal process configuration and the absence of a dorsolateral seta on the first abdominal segment resembles the condition observed for O. gemma (Dennis et al. 2008).

Examined Material: BRAZIL: São Paulo, Luiz Antonio, 21 ${ }^{\circ} 33^{\prime} 18^{\prime \prime} \mathrm{S}$ $47^{\circ} 42^{\prime} 16^{\prime \prime} \mathrm{W}, \mathrm{V} / 22 / 2008,5$ last instar larvae and 1 pupal case, S. P. Rosa and M. Ladenthin col. (MZUSP).
Acknowledgments. We would like to thank Simone Policena Rosa (MZUSP) for having collected the Asilidae larvae, keeping them alive in lab and mainly for providing us the material herein described; Torsten Dikow and an anonymous referee, for reviewing the manuscript. To the Conselho Nacional de Desenvolvimento Científico e Tecnológico (CNPq) for the Master fellowship granted to LAC (Proc. No. 135299/2008-0) and also for the Grant to CJEL (Proc. No. 481024/2008-5).

\section{REFERENCES}

Dennis, D. S.; J. K. Barnes \& L. Knutson. 2008. Pupal cases of Nearctic robber flies (Diptera: Asilidae). Zootaxa 1868: 1-98.

Geller-Grimm, F. 2008. Database Asilidae: Catalog of species. Available from: http://www.geller-grimm.de/catalog/species.htm (accessed 19 November 2008).

Hull, F. M. 1962. Robber flies of the world: the genera of the family Asilidae. United States National Museum Bulletin 224: 1-907.

Musso, J. -J. 1981. Morphology and development of the immature stages of some robber flies. (Diptera: Brachycera: Asilidae). Entomologia Generalis 7: 89-104.

Musso, J. -J. 1983. Nutritive and ecological requirements of robber flies. (Diptera: Brachycera: Asilidae). Entomologia Generalis 9: 35-50.

Peterson, A. 1960. Larvae of Insects. An introduction to Neartic species. Part II (Coleoptera, Diptera, Neuroptera, Siphonaptera, Mecoptera, Trichoptera). 4. ed. Columbus, Edwards Brothers Inc., 416 p.

Scarbrough, A. G. 1993. Revision of the New World species of Ommatius Wiedemann (Diptera: Asilidae): the neotropical costatus species group. Revista de Biologia Tropical 41: 729-753.

Wood, G. C. 1981. Asilidae, p. 549-573. In: J. F. McAlpine; B. V. Peterson; G. E. Shewell; H. J. Teskey; J. R. Vockeroth \& D. M. Wood (Coords). Manual of Nearctic Diptera. Ottawa, Agriculture Canada Research Branch, Monograph 27. 